\title{
Article \\ The Impact of Microbial and Botanical Insecticides on Grape Berry Moths and Their Effects on Secondary Pests and Beneficials
}

\author{
Carlo Duso ${ }^{1, * \mathbb{D}}$, Alberto Pozzebon ${ }^{1}\left(\mathbb{D}\right.$, Mauro Lorenzon ${ }^{1}$, Diego Fornasiero ${ }^{1}$, Paola Tirello ${ }^{1}$, Sauro Simoni ${ }^{2} \mathbb{D}$ \\ and Bruno Bagnoli ${ }^{2}$
}

check for updates

Citation: Duso, C.; Pozzebon, A.;

Lorenzon, M.; Fornasiero, D.; Tirello, P.; Simoni, S.; Bagnoli, B. The Impact of Microbial and Botanical Insecticides on Grape Berry Moths and Their Effects on Secondary Pests and Beneficials. Agronomy 2022, 12, 217. https://doi.org/10.3390/ agronomy 12010217

Academic Editor: Francis Drummond

Received: 9 December 2021

Accepted: 13 January 2022

Published: 16 January 2022

Publisher's Note: MDPI stays neutral with regard to jurisdictional claims in published maps and institutional affiliations.

Copyright: (C) 2022 by the authors. Licensee MDPI, Basel, Switzerland. This article is an open access article distributed under the terms and conditions of the Creative Commons Attribution (CC BY) license (https:// creativecommons.org/licenses/by/ $4.0 /$ )
1 Department of Agronomy, Food, Natural Resources, Animals and Environment (DAFNAE), University of Padova, 35020 Legnaro, Italy; alberto.pozzebon@unipd.it (A.P.); mauro.lorenzon@unipd.it (M.L.); diego.fornasiero@unipd.it (D.F.); paola.tirello@unipd.it (P.T.)

2 CREA-DC, Council for Agricultural Research and Economics, Research Centre for Plant Protection and Certification, 50125 Florence, Italy; sauro.simoni@crea.gov.it (S.S.); bruno.bagnoli@mpcnet.it (B.B.)

* Correspondence: carlo.duso@unipd.it

\begin{abstract}
According to the European Directive 2009/128/EC and the subsequent provisions activated in member states, conventional pesticides should be progressively replaced by "non-chemical tools and/or measures". The identification of reliable alternatives to pesticides is crucial to achieve this objective. A European project (PURE) was funded to investigate this topic with reference to annual and perennial crops. In this framework, a number of natural insecticides, in particular microbial and botanical ones (Bacillus thuringiensis ssp. kurstaki, Beauveria bassiana, azadirachtin, pyrethrins and spinosad) were selected to test their effectiveness against grape berry moths, the key pests in most European vineyards. Trials were conducted in 2011 and 2012 in two experimental vineyards located in Italy (Tuscany and Veneto regions), following a randomized block design. Additional investigations were carried out in the Veneto region during 2013. Trial results stressed the high performance of spinosad and $B$. thuringiensis in controlling berry moth densities and the related damage. The use of $B$. bassiana mixed with $B$. thuringiensis did not significantly improve the impact of $B$. thuringiensis alone. Azadirachtin, and especially pyrethrins, proved to be less effective on berry moths than previous insecticides. The use of selected insecticides caused side-effects on a number of secondary pests, in particular leafhoppers. In 2011, densities of Empoasca vitis were higher in spinosad-treated plots probably because of a reduced egg parasitization rate. One year later, the population density of Zygina rhamni was higher in the plots treated with spinosad or pyrethrins. This trend was confirmed on spinosad-treated plots in the last experimental year. At the same time, spinosad and pyrethrins significantly reduced the predatory mite populations compared to other treatments. The use of these insecticides in viticulture is discussed in the framework of organic viticulture and Integrated Pest Management (IPM).
\end{abstract}

Keywords: Lobesia botrana; Eupoecilia ambiguella; leafhoppers; predatory mites; natural insecticides; damage; side-effects

\section{Introduction}

The European grapevine moth Lobesia botrana (Denis \& Schiffermüller) is a traditional pest of grapes in Europe and the Middle East [1,2] and a new threat in the Americas [3,4]. Lobesia botrana coexists with the grape berry moth Eupoecilia ambiguella (Hübner) in several European regions, such as northern Italy, where they develop three generations per year in most areas and seasons [5]. The impact of L. botrana is increasing in Europe, probably because of climate change [2,6]. Clusters damaged by berry moths can be invaded by fungal diseases and contaminated by ochratoxins [7,8]. Therefore, control measures against berry moths are considered crucial in European vineyards and elsewhere [9]. The active 
ingredients used most in European viticulture against berry moths are methoxyfenozide, emamectin-benzoate and chlorantraniliprole. Another major issue for grapevine is Flavescence dorée, a disease associated with phytoplasmas transmitted mainly by the leafhopper Scaphoideus titanus Ball [10]. Some leafhoppers, such as Empoasca vitis (Goethe), coccids, and mealybugs, such as Parthenolecanium corni Bouché and Planococcus ficus (Signoret), are locally important in European vineyards. Problems with spider mites, mainly Panonychus ulmi (Koch) and Eotetranychus carpini (Oudemans), have also been reported [11].

The use of insecticides in European viticulture is usually lower than that of fungicides, e.g., 3.1 insecticide applications vs. 10.6 fungicide applications per year in Italy in the 2010 growing season [12]. However, this figure can increase dramatically in table grapes due to risks posed by L. botrana, mealybugs and thrips. The occurrence of new pests, such as Drosophila suzukii Matsumura and Erasmoneura vulnerata (Fitch), poses new risks to grapevine production and is increasing insecticide use in some areas $[13,14]$. Pesticide use has been associated with toxicological and environmental problems; a number of frequently used toxic compounds have been banned in the European Union according to Regulation (EC) $1107 / 2009$, and the availability of other active ingredients/formulations in expected to decrease in coming years. Resistance to insecticides and acaricides is a major concern, even if in viticulture this problem is more crucial for pathogens than for arthropod pests. On the other hand, pest resurgence and pesticide-induced pests represent typical implications of insecticide use in viticulture. The reduction in pesticide use by adopting alternative control measures is the objective of Directive 2009/128/EEC. Mating disruption is a reliable control technique against grape berry moths [15], but its performance can be reduced in fragmented habitats and/or hilly and windy areas $[16,17]$. In some areas, S. titanus is more important than berry moths and control measures against this pest are largely based on insecticides. Natural insecticides (e.g., microbial and botanical based insecticides) can be considered alternatives to conventional insecticides to reduce risks to human health and the environment. However, their efficacy is considered low to moderate and, thus, their use is often limited to organic viticulture. Little is known on the effects of natural insecticides against berry moths and other pests of grapes, with the exception of formulations based on Bacillus thuringiensis ssp. kurstaki [18]; at the same time, most studies refer to laboratory trials $[7,19]$. In this study, we evaluate the effectiveness of a number of microbial and botanical insecticides against grape berry moths in two vineyards located in northern and central Italy, in three experimental growing seasons. The potential of natural insecticides in reducing berry moth damage on grapevine yield was evaluated in the last growing season. Their effects on other grapevine pests (e.g., leafhoppers and scales) and some beneficials (e.g., predatory mites) are also considered.

\section{Materials and Methods}

Trials were conducted in two experimental vineyards located in Tuscany (Montepaldi, 2011-2012, vineyard 1) and Veneto (Meolo, 2011-2013, vineyard 2) regions. Average maximum temperatures of the last decades were 20.1 and $18.2{ }^{\circ} \mathrm{C}$ for Montepaldi and Meolo, respectively, while average minimum temperatures were 9.2 and $8.3^{\circ} \mathrm{C}$, respectively. Average rainfall was similar for the two sites (914.8 and $893.8 \mathrm{~mm}$ for Montepaldi and Meolo, respectively). Both vineyards were trained with the espalier system. The vineyard located in Tuscany comprised the Sangiovese cultivar, while that in Veneto the Cabernet Franc cultivar. A number of microbial (i.e., Bacillus thuringiensis ssp. kurstaki, Beauveria bassiana, spinosad) and botanical (i.e., pyrethrins and azadirachtin) insecticides were applied against the second generation of $L$. botrana, following a randomized block design ( $4-5$ replicates per treatment, 8-30 vines per replicate). Regarding B. thuringiensis and B. bassiana, the strains EG 2348 and ATCC 74040 (Rapax ${ }^{\circledR}$ and Naturalis ${ }^{\circledR}$, respectively, Biogard) were used. An untreated control was included for comparison. An additional treatment (i.e., indoxacarb as a toxic reference) was comprised in trials of 2013. Details of insecticide applications are reported in Tables 1 and 2. Vineyards were treated with fungicides to control downy and powdery mildews. 
Table 1. Experimental design of trials conducted in Tuscany (vineyard 1) in 2011 and 2012.

\begin{tabular}{|c|c|c|c|c|}
\hline Treatment & $\begin{array}{c}\text { Active } \\
\text { Ingredient/Microorganism }\end{array}$ & Dose & 2011 & 2012 \\
\hline 1 & Bacillus thuringiensis (Bt) & $100 \mathrm{~g} / \mathrm{hL}$ & 20 and 27 June & 25 June and 3 July \\
\hline 2 & Azadirachtin & $300 \mathrm{~g} / \mathrm{hL}$ & 27 June & 3 July \\
\hline 3 & $\mathrm{Bt}+$ Beauveria bassiana & $100 \mathrm{~g} / \mathrm{hL}+120 \mathrm{~g} / \mathrm{hL}$ & 20 and 27 June & 25 June and 3 July \\
\hline 4 & Spinosad & $20 \mathrm{~mL} / \mathrm{hL}$ & 20 and 27 June & 25 June and 3 July \\
\hline 5 & Pyrethrins & $250 \mathrm{~g} / \mathrm{hL}$ & 27 June and 3 July & 3 and 11 July \\
\hline 6 & Control & - & - & - \\
\hline
\end{tabular}

Table 2. Experimental design of trials conducted in Veneto (vineyard 2) from 2011 to 2013.

\begin{tabular}{|c|c|c|c|c|c|}
\hline Treatment & $\begin{array}{c}\text { Active } \\
\text { Ingredient/Microorganism }\end{array}$ & Dose & 2011 & 2012 & 2013 \\
\hline 1 & Bacillus thuringiensis (Bt) & $100 \mathrm{~g} / \mathrm{hL}$ & 16 and 24 June & 30 June and 7 July & 2 and 9 July \\
\hline 2 & Azadirachtin & $300 \mathrm{~g} / \mathrm{hL}$ & 24 and 29 June & 7 and 14 July & 9 and 16 July \\
\hline 3 & $\mathrm{Bt}+$ Beauveria bassiana & $100 \mathrm{~g} / \mathrm{hL}+120 \mathrm{~g} / \mathrm{hL}$ & 16 and 24 June & 30 June and 7 July & 2 and 9 July \\
\hline 4 & Spinosad & $20 \mathrm{~mL} / \mathrm{hL}$ & 16 and 24 June & 30 June and 7 July & 2 and 9 July \\
\hline 5 & Pyrethrins & $250 \mathrm{~g} / \mathrm{hL}$ & 24 and 29 June & 7 and 14 July & 9 and 16 July \\
\hline 6 & Indoxacarb & $15 \mathrm{~g} / \mathrm{hL}$ & - & - & 2 July \\
\hline 7 & Control & - & - & - & - \\
\hline
\end{tabular}

A total of 100 clusters per treatment (25 per replicate) were sampled approximately one month after the last insecticide applications to assess berry moth damage (\% of infested clusters, number of larval nests per cluster). In 2011, leafhopper populations were sampled in the vineyards by analyzing 100 leaves per treatment (25 leaves per replicate). Additional leaf samples were analyzed in the laboratory to assess densities of leafhoppers, coccids, mealybugs and mites. Regarding the impact of insecticides on beneficial arthropods, observations focused on predatory mites belonging to the Phytoseiidae family. The latter are widely considered as key taxa in the studies on the side-effects of pesticides on nontarget organisms [20-22]. Additional observations were conducted on egg parasitism of leafhoppers (vineyard 2). The parasitization rate of E. vitis and Z. rhamni eggs by Anagrus spp. (Hymenoptera: Chalcidoidea Mymaridae) was calculated by dividing the number of eggs with parasitoid emergence holes by the sum of normally hatched leafhopper eggs and eggs with parasitoid emergence holes.

Data on berry moth incidence (\% of infested clusters) were analyzed using a logistic regression with the GENMOD procedure of SAS ${ }^{\circledR}$ (ver. 9.4) and considering the ratio between infested clusters over the total number of clusters as dependent variable with binomial distribution. The treatment effect was evaluated with an $\chi^{2}$ test $(\alpha=0.05)$. Using the LSMEAN statement, we performed a Wald $\chi^{2}$ test on the pairwise comparison of different treatments $(\alpha=0.05)$. Data on larval nests per cluster were analyzed using general linear model with the GLM procedure of SAS ${ }^{\circledR}$. An F-test $(\alpha=0.05)$ was used to assess effect of treatment, followed by a Tukey post hoc test $(\alpha=0.05)$. Data on larval nests per cluster were checked for normality and homoscedasticity prior to the analysis, and a $\log (x+1)$ transformation was applied to meet model assumptions.

Data obtained by the analysis of leaf samples were analyzed with a linear mixed repeated measures model with MIXED procedure of SAS ${ }^{\circledR}$ (ver. 9.4). Data on leafhoppers, scales and mites were analyzed separately and considered as response variables with repeated measures determined at different times corresponding to the different sampling dates. Using an F-test $(\alpha=0.05)$, we evaluated the effect of treatment, time and their interactions. Slice option of the LSMEANS statement was used for the F-test partition of interactions between insecticide application and time. Contrasts were designed to assess differences among treatments and tested using a $t$-test $(\alpha=0.05)$. Moreover, differences among treatments at each sampling date were evaluated using a t-test to the least-square 
means $(\alpha=0.05)$. The Kenward-Roger method was used for degrees of freedom estimation, which can yield degrees of freedom with non-integer values. Data were checked for analysis assumptions prior to the analysis, and $\log (x+1)$ transformation was used to meet model assumptions.

\section{Results}

\subsection{Effects on Grape Berry Moths}

In both vineyards, captures of berry moth adults on pheromone traps revealed the dominance of L. botrana over E. ambiguella. Most larvae of berry moths found on clusters belonged to $L$. botrana. Therefore, the effects of insecticides were considered with reference to this species. In vineyard 1 , insecticide use affected the berry moth incidence in the first experimental season (2011) $\left(\chi^{2}=28.78 ; \mathrm{df}=5 ; p<0.0001\right)$; however, only spinosad obtained a significant control of L. botrana (Figure 1). The effect of azadirachtin did not differ from the control, and the remaining treatments were associated with intermediate values. No differences among treatments were noticed in terms of larval densities $(\mathrm{F}=0.78 ; \mathrm{df}=5,18$; $p=0.574 ;$ Figure 1). In 2012, the effect of insecticides was significant $\left(\chi^{2}=18.63 ; \mathrm{df}=5\right.$; $p=0.002 ; \mathrm{F}=1.88 ; \mathrm{df}=5,20 ; p=0.143$, respectively, for berry moth damage and larval densities), but only spinosad was effective in reducing berry moth damage and larval densities (Figure 1).
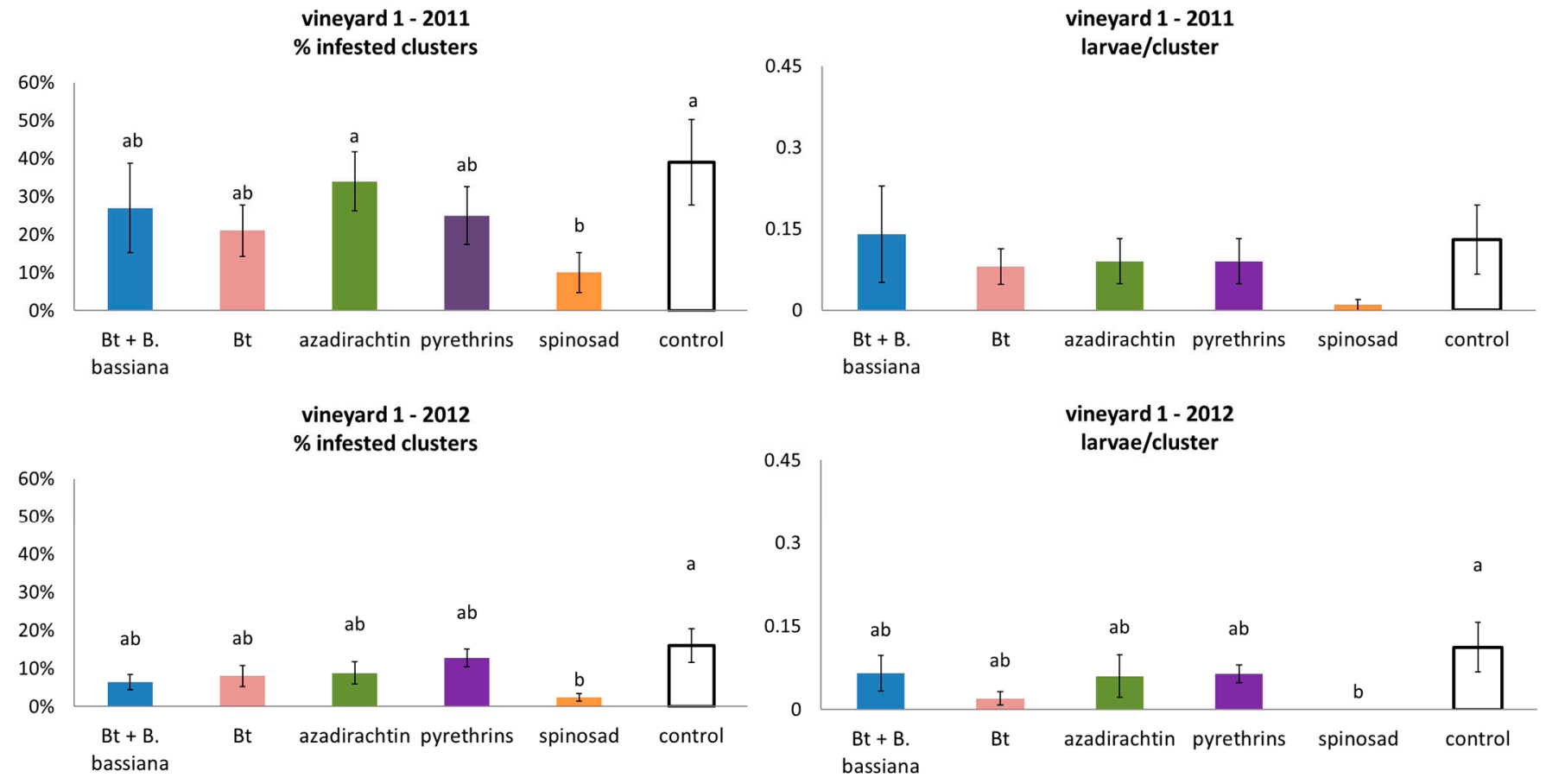

Figure 1. Effects of insecticide treatments on damage caused by berry moth larvae and their densities in two subsequent seasons (vineyard 1, Montepaldi, Tuscany, Italy) (Bt = Bacillus thuringiensis). Different letters indicate significant differences at $t$-test $(p=0.05)$.

In vineyard 2, insecticides applied in 2011 caused significant effects on both berry moth incidence and larval densities $\left(\chi^{2}=61.81 ; \mathrm{df}=5 ; p<0.0001 ; \mathrm{F}=12.27 ; \mathrm{df}=5,15 ; p<0.0001\right.$, respectively). The best infestation reduction was noticed when spinosad and $B$. thuringiensis (with or without B. bassiana) were applied (Figure 2). The impact of azadirachtin was also significant in contrast with that of pyrethrins. The effects of these insecticides on larval densities followed the previous trend (Figure 2). In 2012, the effects of insecticides were confirmed to be significant and berry moth control in terms of incidence was higher when spinosad, azadirachtin and B. thuringiensis (especially with B. bassiana) were applied $\left(\chi^{2}=42.38 ; \mathrm{df}=5 ; p<0.0001\right.$; Figure 2). Larval densities were limited following a similar 
tendency $(\mathrm{F}=11.54 ; \mathrm{df}=5,15 ; p<0.0001$; Figure 2). The infestation level of 2013 was higher than that observed in previous growing seasons. The effect of insecticides on the berry moth incidence was significant $\left(\chi^{2}=145.07 ; \mathrm{df}=5 ; p<0.0001\right)$ and spinosad obtained the best results in terms of berry moth control (Figure 2). The effectiveness of $B$. thuringiensis was comparable to that of indoxacarb; azadirachtin and pyrethrins showed a lower impact. The control level of larval populations obtained using spinosad did not differ from that of indoxacarb, and results obtained using the latter insecticide were not significantly different from those reported for $B$. thuringiensis or azadirachtin $(\mathrm{F}=26.21$; $\mathrm{df}=5,19 ; p<0.0001)$.
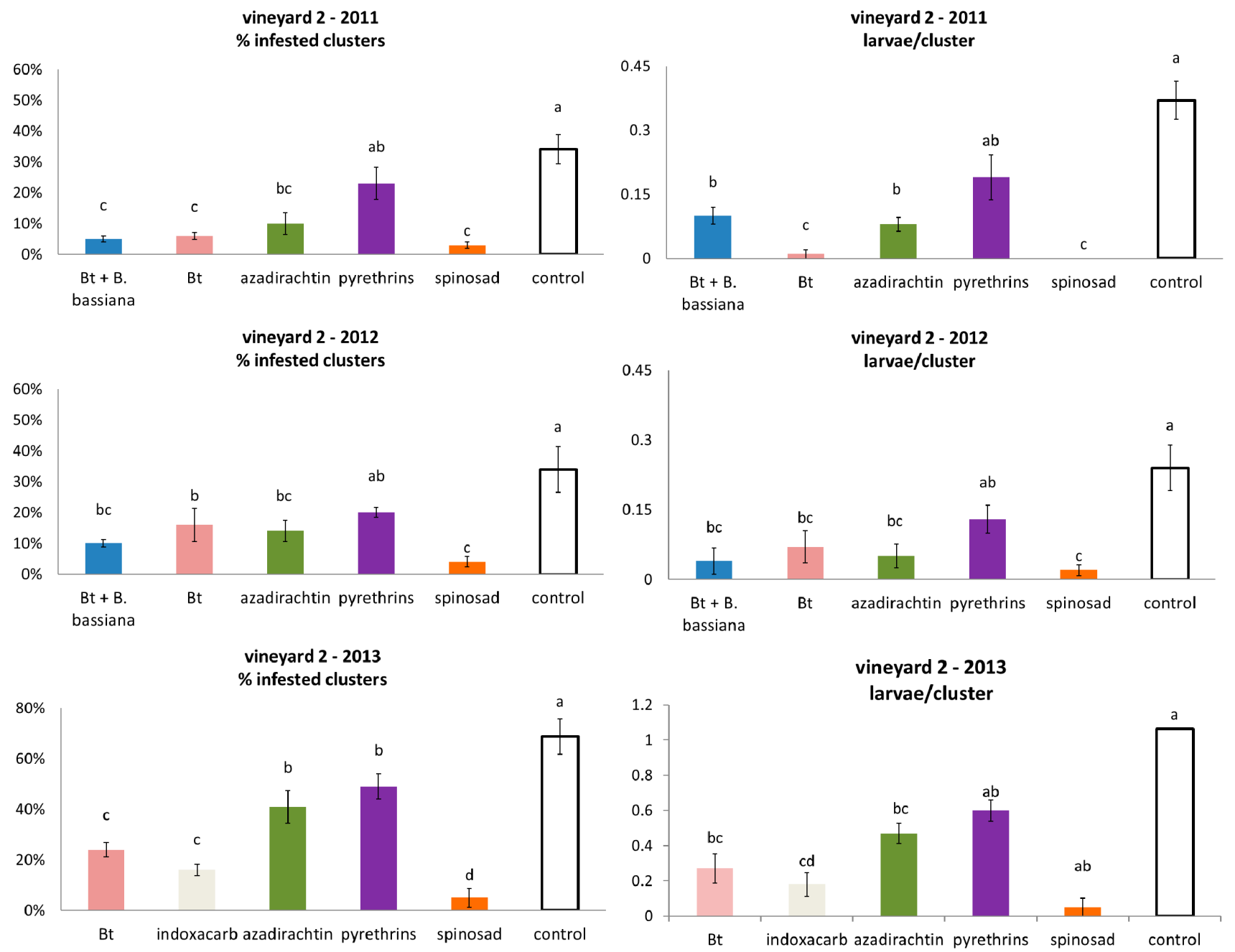

Figure 2. Effects of insecticide treatments on damage caused by berry moth larvae and their densities in three subsequent seasons (vineyard 2, Meolo, Veneto, Italy) $(\mathrm{Bt}=$ Bacillus thuringiensis). Different letters indicate significant differences at $t$-test $(p=0.05)$.

\subsection{Effects on Damage Caused by Berry Moths}

The impact of berry moths on the grapevine yield was assessed in 2013. The effect of the treatment was significant $(\mathrm{F}=4.52 ; \mathrm{df}=5,114 p=0.0009)$ and the cluster weight was significantly reduced in the control plots compared to those treated with spinosad, B. thuringiensis and indoxacarb (Figure 3). The remaining treatments showed intermediate results. 


\section{Cluster weight}

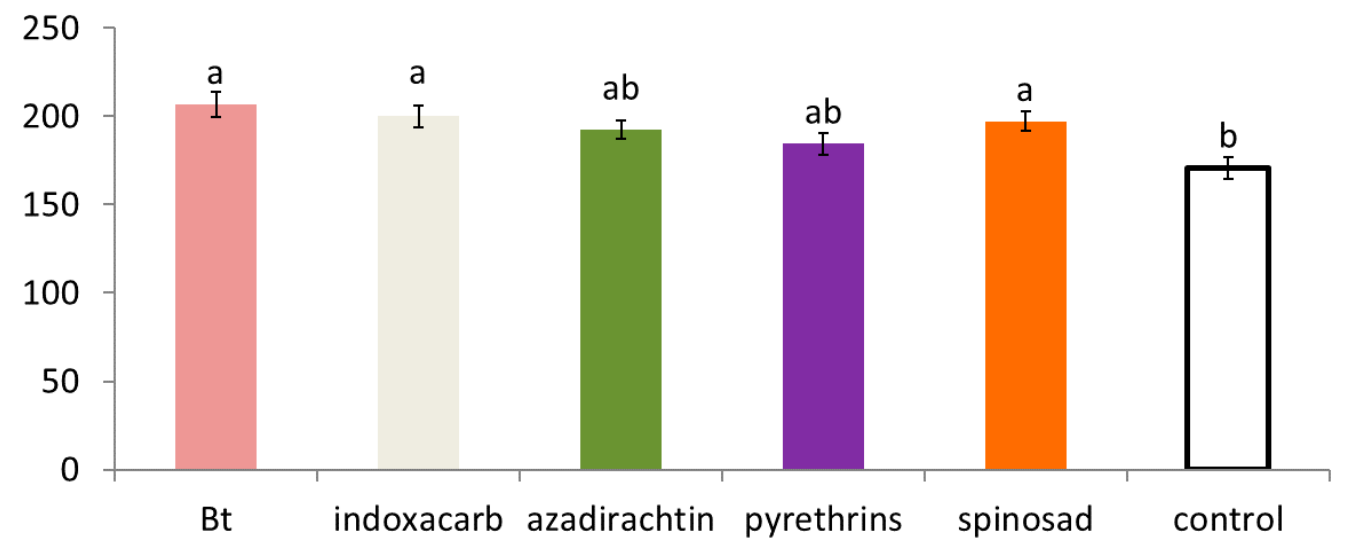

Figure 3. Effect on grape yield (mean cluster weight in $\mathrm{g}$ ) of natural and conventional insecticides applied to control berry moths in vineyard 2 in 2013 (Bt = Bacillus thuringiensis). Different letters indicate significant differences at $t$-test $(p=0.05)$.

\subsection{Effects on Leafhoppers}

During 2011, the occurrence of leafhoppers in vineyard 1 was negligible. In the same year, the most interesting results were observed in vineyard 2, where E. vitis and Z. rhamni were common. A field evaluation was performed in late July when differences among treatments were significant for $E$. vitis $(\mathrm{F}=7.93 ; \mathrm{df}=5,15 ; p<0.001)$. The highest leafhopper densities were found on spinosad plots compared to the control and other treatment plots (Figure 4). Regarding Z. rhamni, there were no differences among treatments $(\mathrm{F}=1.13$; $\mathrm{df}=5,15 ; p=0.385$; Figure 4). When the second generation of E. vitis was completed (early August), the parasitization rate of leafhopper eggs caused by Anagrus spp. was evaluated. The parasitization rate was significantly lower on spinosad plots compared to the other treatments $\left(\chi^{2}=16.55 ; \mathrm{df}=5 ; p<0.001\right.$; Figure 4$)$.

A picture of the leafhopper seasonal abundance in 2011 was obtained by analyzing leaf samples in the laboratory. Regarding E. vitis, results showed significant differences among treatments (Table 3; Figure 5), with higher E. vitis densities occurring on spinosad-treated plots as compared to other treatments, except for B. bassiana, which showed intermediate infestation levels (Figure 5). The occurrence of Z. rhamni was lower and data were not analyzed (Table 3; Figure 5).

Table 3. Results of linear mixed repeated measures model analysis of data on leafhoppers, scales and mites observed in 2011, 2012 and 2013.

\begin{tabular}{|c|c|c|c|c|}
\hline & & Treatment & Time & Treatment $\times$ Time \\
\hline \multirow[t]{3}{*}{ Empoasca vitis } & 2011 & $\mathrm{~F}=2.99 ; \mathrm{df}=5,32.5 ; p=0.025$ & $\mathrm{~F}=15.53 ; \mathrm{df}=4,69.7 ; p<0.0001$ & $\mathrm{~F}=1.44 ; \mathrm{df}=20,70.9 ; p=0.132$ \\
\hline & 2012 & $\mathrm{~F}=1.55 ; \mathrm{df}=5,46.9 ; p=0.692$ & $\mathrm{~F}=12.53 ; \mathrm{df}=6,101 ; p<0.0001$ & $\mathrm{~F}=1.55 ; \mathrm{df}=30,102 ; p=0.055$ \\
\hline & 2013 & $\mathrm{~F}=5.47 ; \mathrm{df}=5,43.7 ; p<0.001$ & $\mathrm{~F}=57.81 ; \mathrm{df}=7,120 ; p<0.0001$ & $\mathrm{~F}=2.21, \mathrm{df}=35,122 ; p<0.001$ \\
\hline \multirow[t]{3}{*}{ Zygina rhamni } & 2011 & n.a. & n.a. & n.a. \\
\hline & 2012 & $\mathrm{~F}=1.23 ; \mathrm{df}=5,23.8 ; p=0.324$ & $\mathrm{~F}=112.49 ; \mathrm{df}=4,67.1 ; p<0.0001$ & $\mathrm{~F}=3.55 ; \mathrm{df}=20,67.6 ; p<0.0001$ \\
\hline & 2013 & $\mathrm{~F}=2.65 ; \mathrm{df}=5,40.9 ; p=0.037$ & $\mathrm{~F}=93.34 ; \mathrm{df}=7,117.0 ; p<0.0001$ & $\mathrm{~F}=1.11 ; \mathrm{df}=35,120 ; p=0.331$ \\
\hline $\begin{array}{c}\text { Parthenolecanium } \\
\text { corni }\end{array}$ & 2012 & $\mathrm{~F}=2.14, \mathrm{df}=5,53.8 ; p=0.074$ & $\mathrm{~F}=56.04, \mathrm{df}=6,139 ; p<0.0001$ & $\mathrm{~F}=1.55, \mathrm{df}=30,142 ; p=0.048$ \\
\hline \multirow{5}{*}{$\begin{array}{c}\text { Predatory } \\
\text { mites-vineyard } 1 \\
\text { Predatory } \\
\text { mites-vineyard } 2\end{array}$} & 2011 & $\mathrm{~F}=3.12 ; \mathrm{df}=5,80 ; p=0.013$ & $\mathrm{~F}=12.42 ; \mathrm{df}=4,80 ; p<0.0001$ & $\mathrm{~F}=0.87 ; \mathrm{df}=20,80 ; p=0.618$ \\
\hline & 2012 & $\mathrm{~F}=5.71 ; \mathrm{df}=5,168 ; p<0.0001$ & $\mathrm{~F}=27.80 ; \mathrm{df}=6,168 ; p<0.0001$ & $\mathrm{~F}=1.18 ; \mathrm{df}=30,168 ; p=0.258$ \\
\hline & 2011 & $\mathrm{~F}=10.04 ; \mathrm{df}=5,80 ; p<0.0001$ & $\mathrm{~F}=70.30 ; \mathrm{df}=4,80 ; p<0.0001$ & $\mathrm{~F}=2.00 ; \mathrm{df}=20,80 ; p=0.016$ \\
\hline & 2012 & $\mathrm{~F}=40.96 ; \mathrm{df}=5,108 ; p<0.0001$ & $\mathrm{~F}=16.50 ; \mathrm{df}=5,108 ; p<0.0001$ & $\mathrm{~F}=6.33 ; \mathrm{df}=25,108 ; p<0.0001$ \\
\hline & 2013 & $\mathrm{~F}=18.24 ; \mathrm{df}=5,43.7 ; p<0.0001$ & $\mathrm{~F}=31.24 ; \mathrm{df}=7,115 ; p<0.0001$ & $\mathrm{~F}=2.82 ; \mathrm{df}=35,119 ; p<0.0001$ \\
\hline
\end{tabular}




\section{Empoasca vitis}

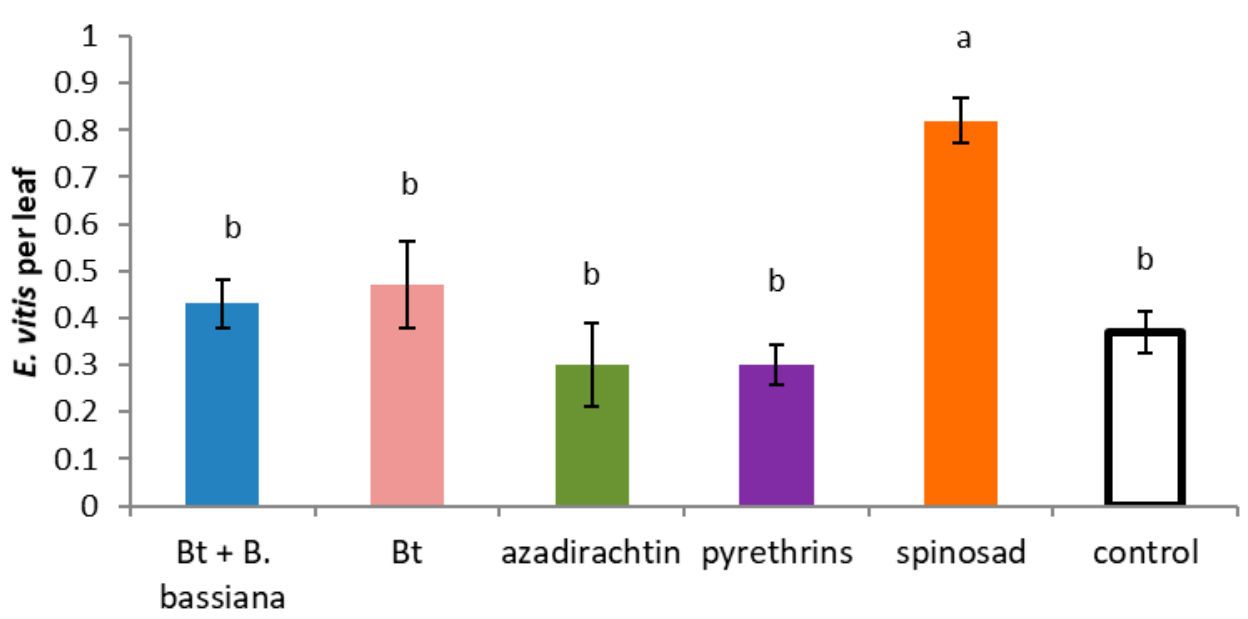

Zygina rhamni

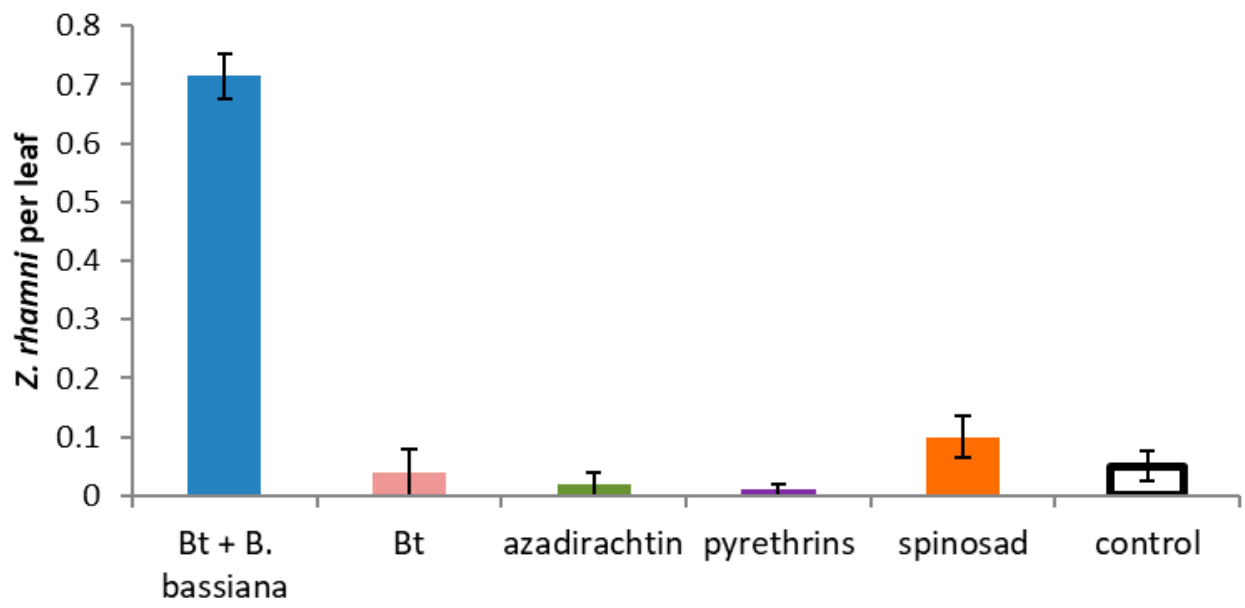

Parasitization rate by Anagrus spp.

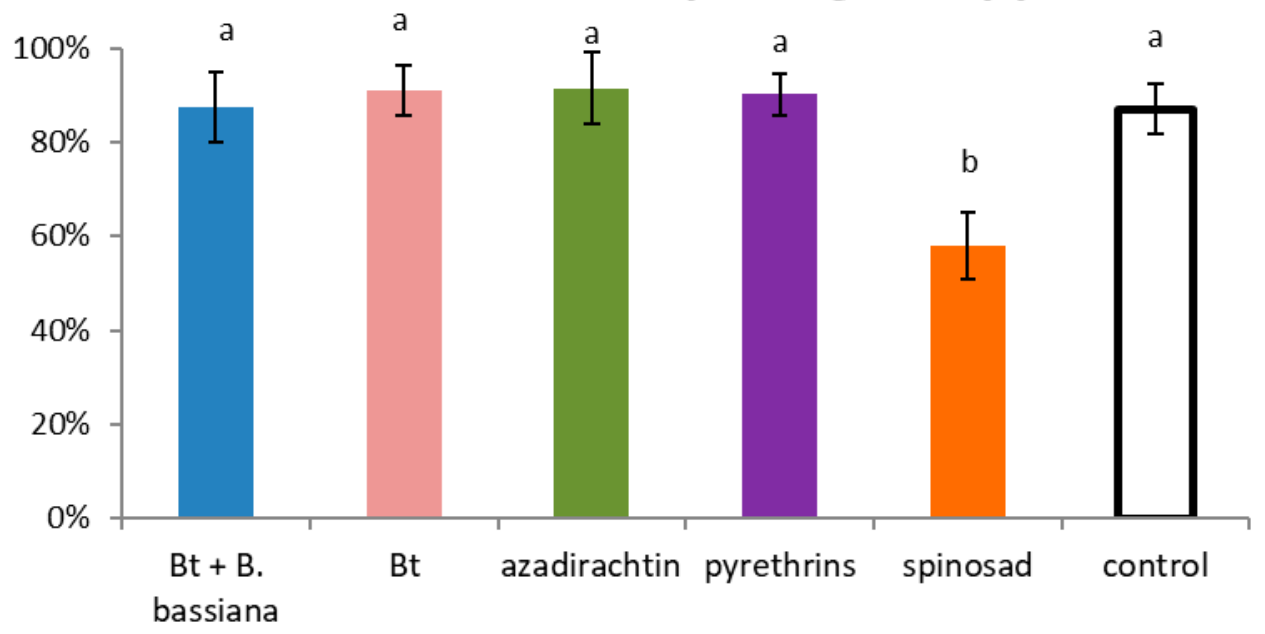

Figure 4. Effects of insecticide treatments on leafhopper density and parasitization rate of leafhopper eggs in vineyard 1 in the 2011 growing season $(\mathrm{Bt}=$ Bacillus thuringiensis). Different letters indicate significant differences at $t$-test $(p=0.05)$. 
Empoascavitis 2011

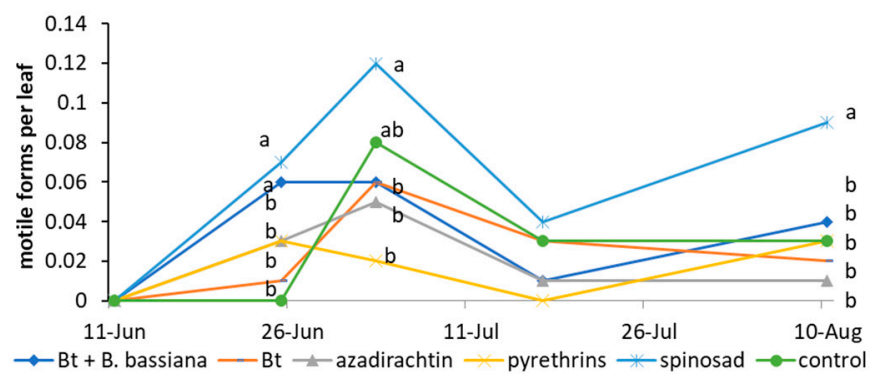

Empoascavitis

2012

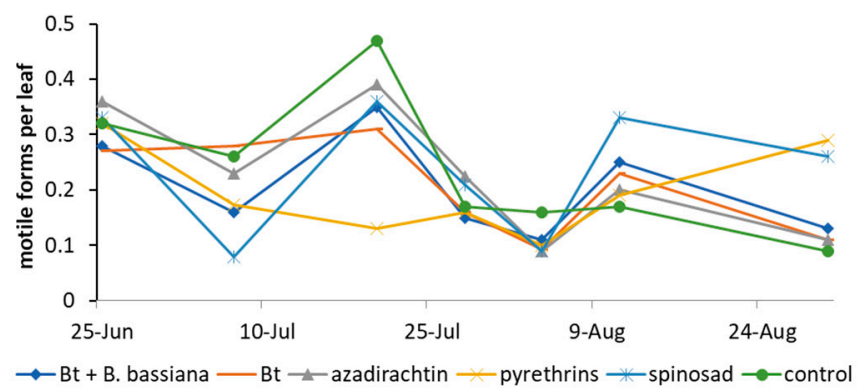

Empoascavitis

2013

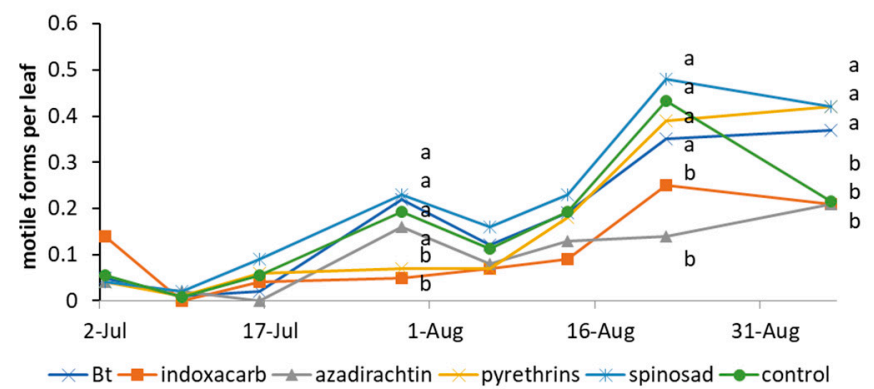

Zygina rhamni

2011

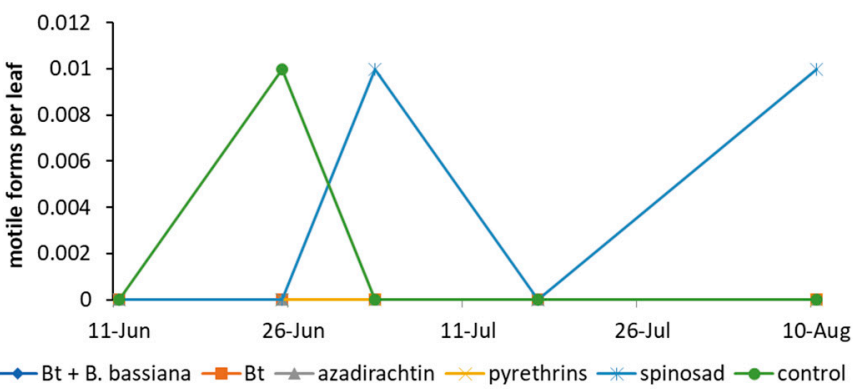

Zygina rhamni

2012

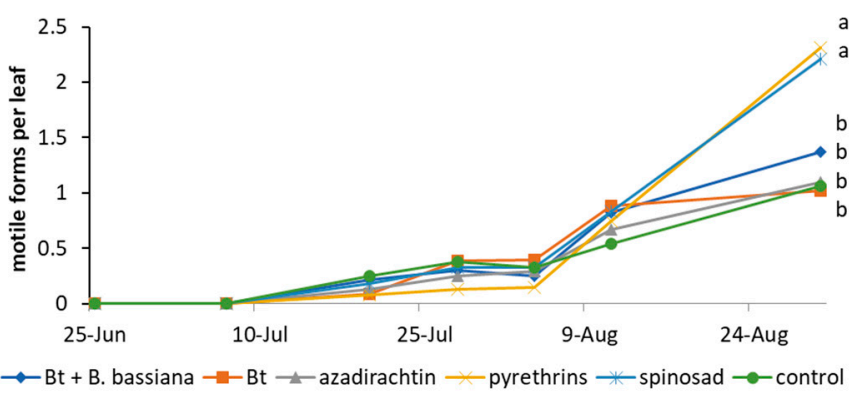

Zygina rhamni

2013

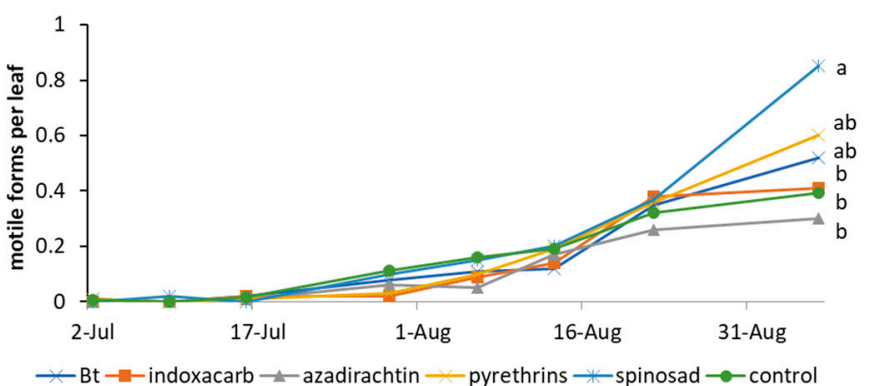

Figure 5. Effects of insecticide treatments on leafhopper population in vineyard 2 during three subsequent growing seasons $(\mathrm{Bt}=$ Bacillus thuringiensis). Different letters indicate significant differences at $t$-test $(p=0.05)$ among treatments on the same sampling date.

In 2012, leafhopper population densities were estimated analyzing leaf samples in the laboratory. Regarding the E. vitis abundance, there were no significant differences among treatments (Table 2). The effect of time was significant (Table 3) in contrast with the interaction "time $\times$ treatment" (Table 3). Regarding Z. rhamni, differences among treatments were not significant (Table 3), while the effect of time and interaction "treatment $\times$ time" were (Table 3). From the analysis performed over the sampling period, differences emerged in late season (Table 3), when higher densities of Z. rhamni were found on spinosad and pyrethrins than on the other treatments (Figure 5). The parasitization rate by Anagrus spp. attained the highest values (34\%) in the control and the lowest (13\%) in spinosad plots. However, differences among treatments were not significant $\left(\chi^{2}=0.87 ; \mathrm{df}=5 ; p=0.522\right)$.

Moderate E. vitis densities occurred in leaf samples in 2013, but differences among treatments were significant (Table 3); in particular, higher densities were detected in the control, B. thuringiensis and spinosad compared to indoxacarb and azadirachtin treatments (Figure 5). The effect of time and the interaction "time $\times$ treatment" were also significant (Table 3). Z. rhamni populations increased in late season and differences among treatments were significant (Table 3; Figure 5); leafhopper densities were higher on spinosad than on 
indoxacarb and azadirachtin-treated plots (Figure 5). The effect of time was significant (Table 3) in contrast with interaction "treatment $\times$ time" (Table 3). In 2013, the parasitism rate by the Mymaridae reached low levels (<20\%) with no differences among treatments.

\subsection{Effects on Scales}

The occurrence of coccids and mealybugs in both vineyards was generally low. However, insecticides caused significant effects on P. corni populations in the 2012 growing season. In vineyard 1, the effect of treatments was not significant (Table 3) in contrast with that of time and interaction "treatment $\times$ time" (Table 3). Differences among treatments were recorded in July, when higher coccid densities were found in the control, azadirachtin and spinosad than in the B. thuringiensis $+B$. bassiana treatment (Figure 6).

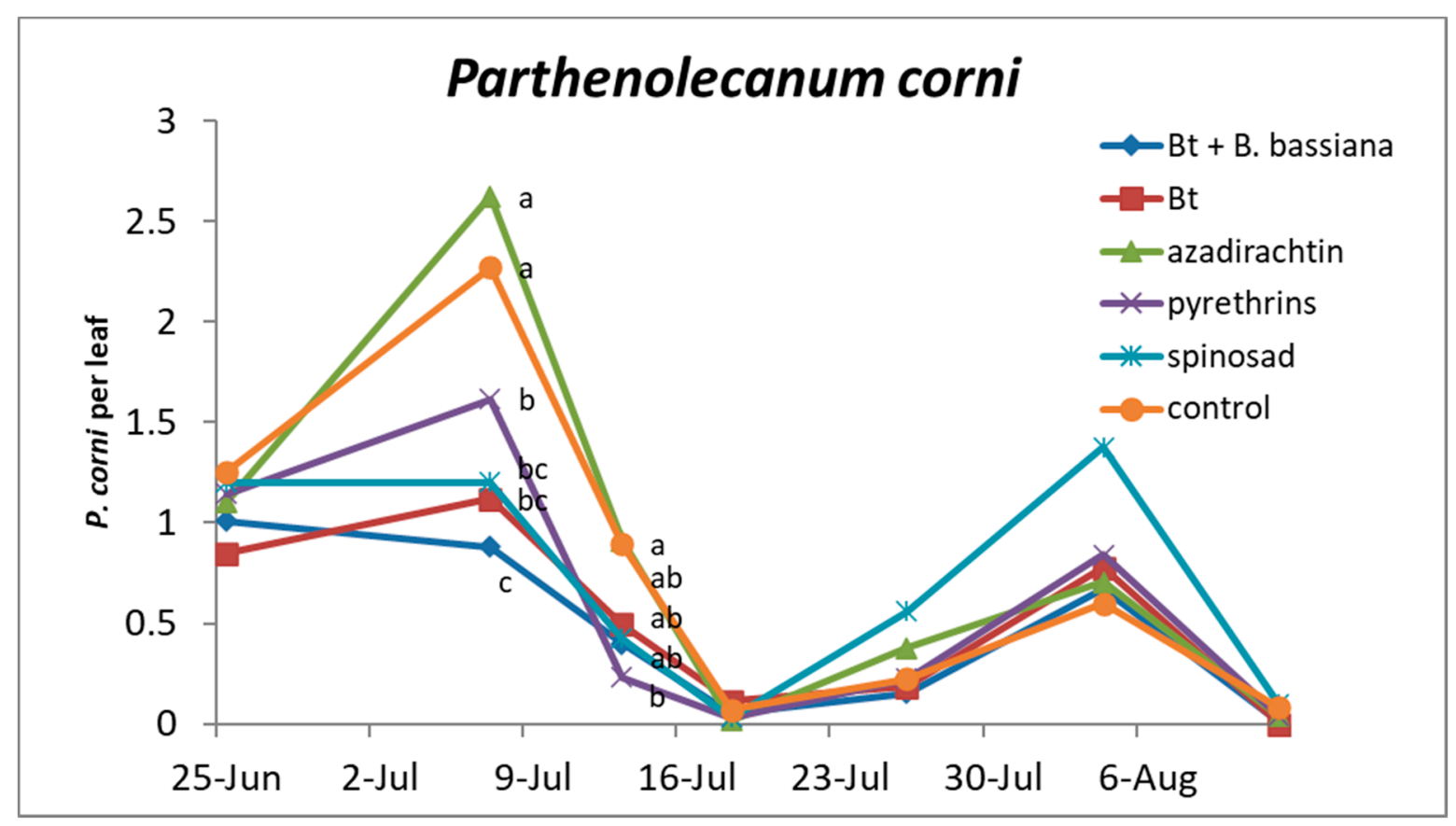

Figure 6. Effects of insecticide treatments on Parthenolecanium corni in vineyard 1 in the 2011 growing season $(\mathrm{Bt}=$ Bacillus thuringiensis). Different letters indicate significant differences at $t$-test $(p=0.05)$ among treatments on the same sampling date.

In 2013, mealybugs reached moderate levels in vineyard 2, but differences among treatments were not significant $(\mathrm{F}=1.11 ; \mathrm{df}=5,20.3 ; p=0.387$; data not shown).

\subsection{Effects on Predatory Mites}

Phytophagous mites (Acari: Tetranychoidea, Eriophyoidea) were recorded at very low densities in both vineyards. Predatory mites belonging to the Phytoseiidae family were commonly detected, in particular Typhlodromus pyri Scheuten, which dominated in vineyard 1, Amblyseius andersoni (Chant) and Phytoseius finitimus Ribaga in vineyard 2.

In vineyard 1, a number of insecticides applied in 2011 caused significant effects on predatory mite populations (Table 3). The effect of time was significant (Table 3) in contrast with that of the interaction "time $\times$ treatment" (Table 3). Prior to insecticides applications, there were no differences among treatments (Table 3). Later, predatory mite densities were significantly reduced in spinosad-treated plots compared to the control, B. thuringiensis and azadirachtin plots (Figure 7). There were no differences between spinosad, pyrethrins and B. thuringiensis $+B$. bassiana. 
vineyard 1 - 2011

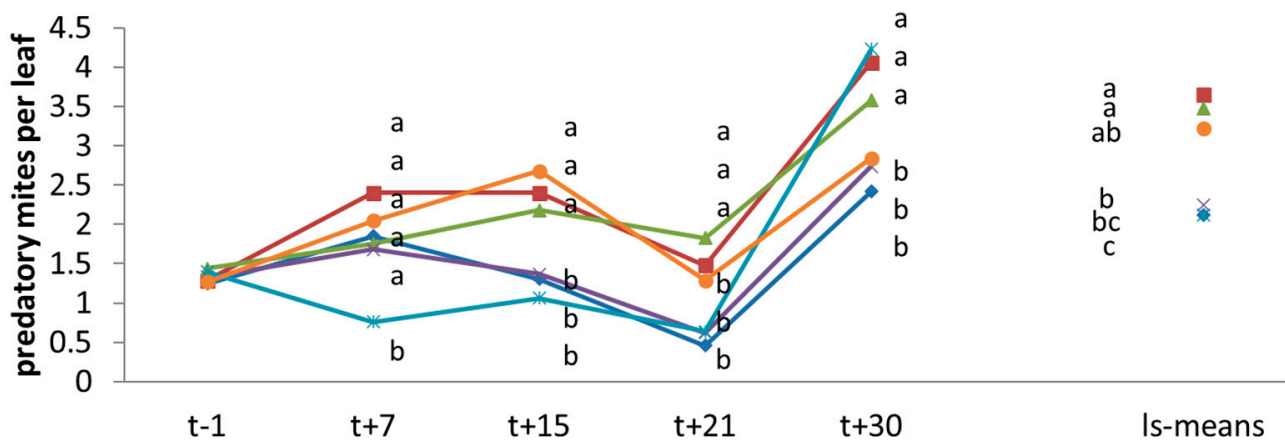

vineyard 1 - 2012

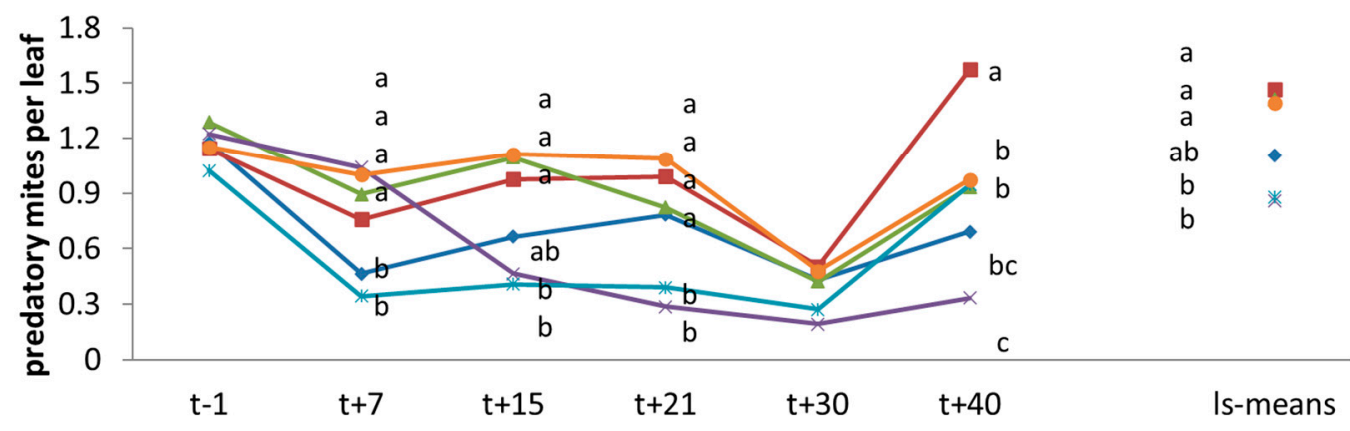

$\rightarrow$ Bt + B. bassiana $\rightarrow$ B. thuringensis - azadirachtin $*$ pyrethrins $*$ spinosad $\rightarrow$-control

Figure 7. Effects of insecticide treatments on predatory mites in two subsequent growing seasons (2011, 2012) in vineyard 1 (Montepaldi, Tuscany, Italy; Bt = Bacillus thuringiensis). Different letters indicate significant differences at $t$-test $(p=0.05)$.

One year later, the effect of insecticides on T. pyri populations was confirmed to be significant (Table 3). The effect of time was also significant (Table 3), in contrast with the interaction "time $\times$ treatment" (Table 3). There were no differences among treatments before insecticide applications ( $\mathrm{F}=0.11 ; \mathrm{df}=5,168 ; p=0.989)$. Then, the use of spinosad and pyrethrins was associated with a decrease in predatory mite numbers compared to the control, $B$. thuringiensis and azadirachtin (Figure 7). There were no differences between B. thuringiensis $+B$. bassiana and the other treatments.

The effect of insecticides on predatory mites was also significant in vineyard 2 (Table 3). The effects of time were significant in the three growing seasons (Table 3 ). The interaction "time $\times$ treatment" was also significant (Table 3).

Prior to insecticide applications, differences among treatments were not significant $(\mathrm{F}=0.29 ; \mathrm{df}=5,80 ; p=0.917 ; \mathrm{F}=0.21 ; \mathrm{df}=5,108 ; p=0.958 ; \mathrm{F}=1.05 ; \mathrm{df}=5,151 ; p=$ 0.384; respectively in 2011, 2012 and 2013), while significant effects were observed later. In the first season, the use of spinosad and of pyrethrins reduced predatory mite densities compared to the control, B. thuringiensis and azadirachtin (Figure 8). The mixture between B. thuringiensis and B. bassiana was also associated with lower densities compared to the control (Figure 8). One year later, the impact of spinosad and pyrethrins was the most severe, followed by that of B. thuringiensis + B. bassiana and azadirachtin (Figure 8). In the third season, the applications of spinosad and pyrethrins caused significant reductions in the number of predatory mites as compared to other treatments (Figure 8). 
vineyard 2 - 2011

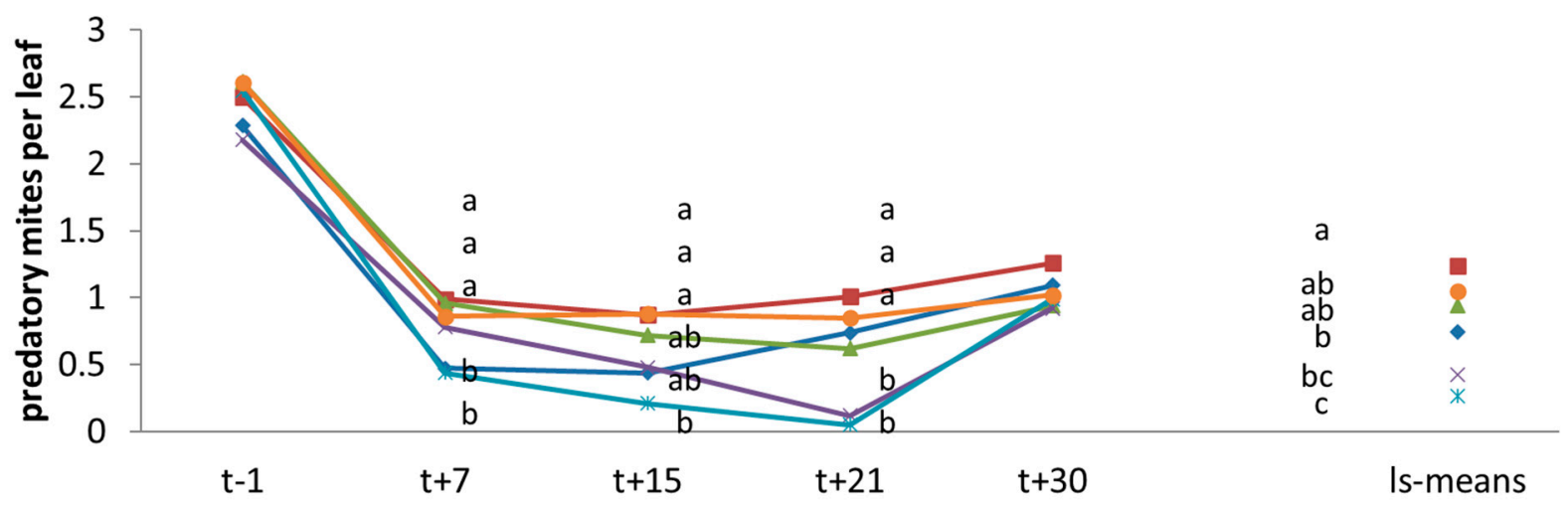

$\rightarrow \mathrm{Bt}+$ B. bassiana $\rightarrow$-B. thuringensis $\_$azadirachtin $*$ pyrethrins $*$ spinosad $\rightarrow$-control

vineyard 2 - 2012

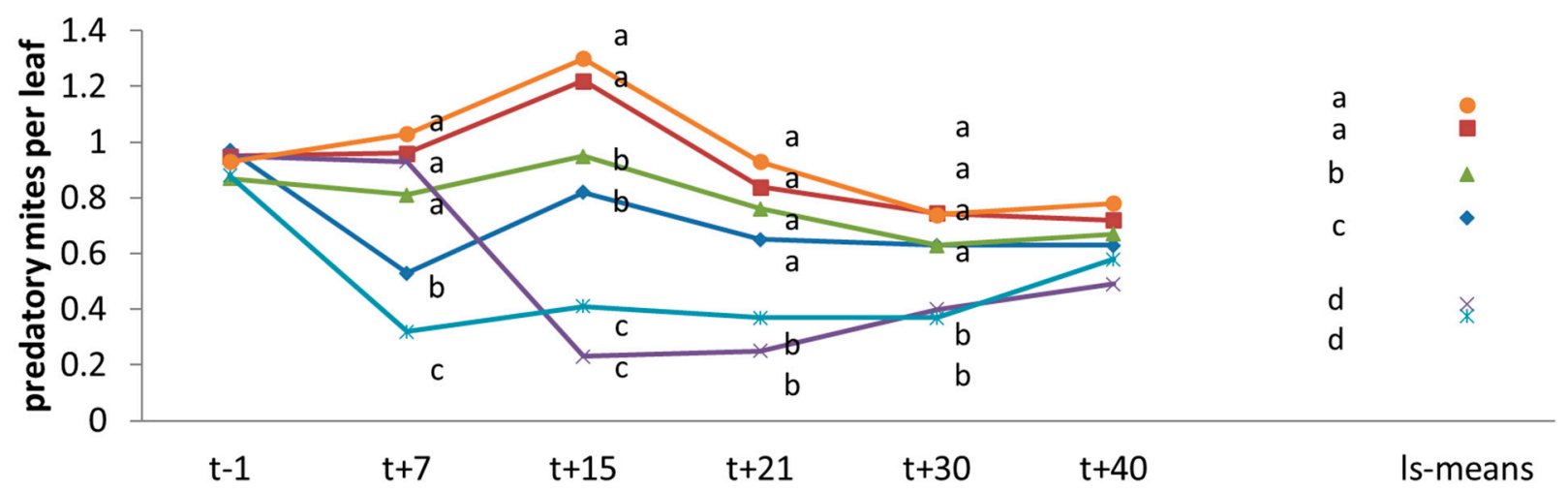

$\rightarrow \mathrm{Bt}+$ B. bassiana $\rightarrow-$ B. thuringensis $\leftarrow$ azadirachtin $*$ pyrethrins $*$ spinosad $\rightarrow$-control

vineyard 2 - 2013

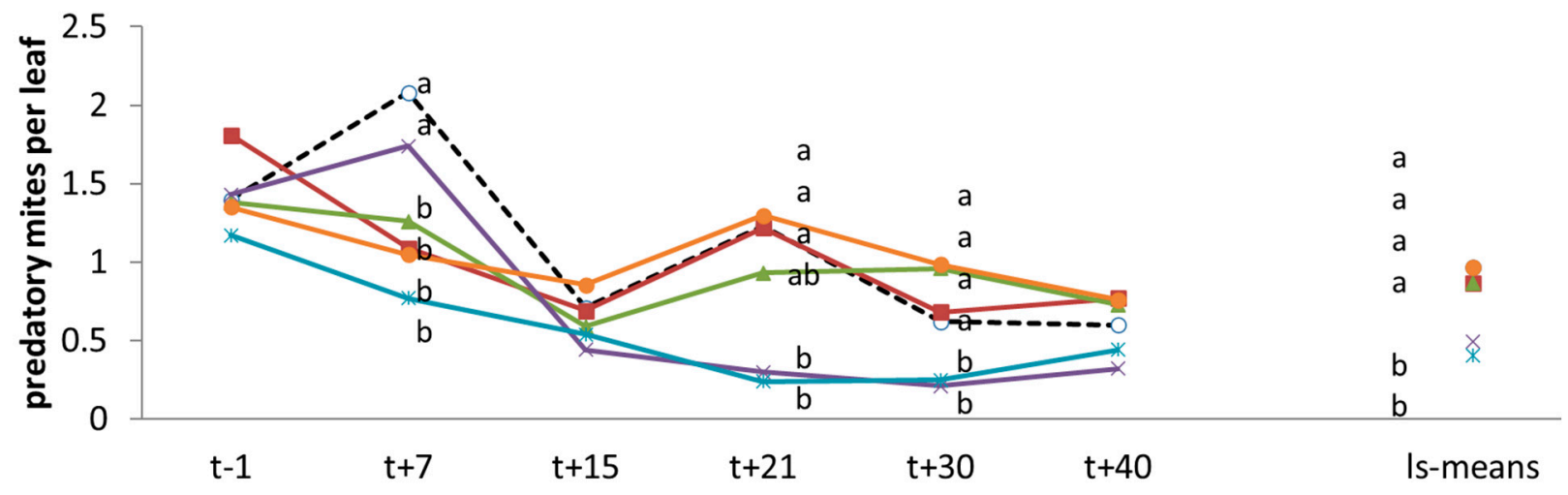

$-\circ$-indoxacarb $\rightarrow$-B. thuringensis $\rightarrow$ azadirachtin $\rightarrow$ pyrethrins $*$ spinosad $\rightarrow-$ control

Figure 8. Effects of insecticide treatments on predatory mites in three subsequent growing seasons $(2011,2012,2013)$ in vineyard 2 (Meolo, Veneto, Italy; Bt = Bacillus thuringiensis). Different letters indicate significant differences at $t$-test $(p=0.05)$. 


\section{Discussion}

The main scope of these trials was to identify reliable alternatives to conventional insecticides in controlling grape berry moths. The evaluation of these tools was extended to their side-effects on some secondary pests and natural enemies to delineate a more comprehensive picture of their impact on arthropod communities associated with a definite crop system. Results highlighted the efficacy of spinosad and B. thuringiensis against grape berry moths compared to the other insecticides, including indoxacarb. Therefore, biopesticides can compete with conventional insecticides in controlling key pests. On the other hand, side-effects of tested insecticides were very different providing interesting data in different scenarios.

Spinosad was the most effective insecticide in controlling berry moths in the five trials, and in the last experimental year it was more effective than indoxacarb, a widely used insecticide in conventional viticulture. It is remarkable that the effects of spinosad on grapevine pests were poorly explored in the literature. It proved to be an effective tool in controlling L. botrana and thrips in southern Europe [23]. More recently, the efficacy of spinosad in controlling D. suzukii before oviposition was suggested in laboratory trials [24]. On the other hand, spinosad was tested against $S$. titanus, obtaining unsatisfactory results compared with other natural pesticides [25]. Our results showed that the use of spinosad can be associated with an increase in leafhopper and scale densities. Moreover, we found a negative effect of spinosad on the natural antagonists of pests. In the first experimental season, spinosad affected the leafhopper parasitization rate by mymarids, but this effect was not confirmed in the subsequent trials. Spinosad dramatically reduced predatory mite densities, confirming the results of trials conducted on other predatory mite species $[26,27]$. Caution about spinosad use has been expressed in a review devoted to the effects of spynosins on beneficial arthropods [28], and recent literature provides several examples of such effects $[29,30]$.

Bacillus thuringiensis obtained a satisfactory control of berry moths in vineyard 2, while it was less effective in vineyard 1. Factors affecting these differences were not clear; perhaps the higher population densities of berry moths in vineyard 2 could have been involved. B. thuringiensis was considered an alternative to conventional pesticides in the 1970s, but the contrasting results in terms of efficacy against berry moths limited its practical use. New formulations characterized by a higher efficacy and stability were recently proposed and an improved knowledge about $B$. thuringiensis (strains, formulation, timing and frequency of application, spray volume) allowed Bt-based formulations (ssp. kurstaki or aizawai) to be evaluated again $[18,31]$.

The mixture between $B$. thuringiensis and B. bassiana did not improve the results obtained by $B$. thuringiensis alone. Various entomopathogen fungi, including $B$. bassiana, have been proposed as biocontrol agents against different pests, but results obtained in viticulture are limited to a few species. An experimental strain of B. bassiana 432 (ITEM1559) was tested against $L$. botrana in southern Italy, obtaining a reduction in berry moth damage and OTA contamination [7]. Beauveria bassiana has been tested against spider mites and thrips with good results [32] (Simoni S., pers. comm). Therefore, a formulation based on B. bassiana (ATCC 74040 strain) was authorized for the control of thrips and spider mites in Italian vineyards, and this formulation was used in our trials. While B. thuringiensis was confirmed to be a fully selective bioinsecticide, the present work showed that the mixture between $B$. thuringiensis and B. bassiana reduced predatory mite densities in some trials.

The effect of botanical pesticides on grapevine pests, including berry moths, has not been widely investigated. In some of our trials, azadirachtin showed results comparable with those of $B$. thuringiensis, while in others, its performance was lower. The application of azadirachtin to L. botrana larvae resulted in an inability to molt properly as well as deformities, a reduction in fecundity and fertility and a reduction in egg hatching [19]. In our trials, azadirachtin proved to be relatively harmless towards predatory mites.

Finally, the use of pyrethrins was associated with the worst results in terms of berry moth control and a decline in predatory mite densities. This insecticide proved to be the 
most effective in controlling $S$. titanus as compared to other natural pesticides [25], but is not recommended for the control of berry moths.

\section{Conclusions}

Natural insecticides can replace conventional ones in controlling grape berry moths, the key grapevine pests in Europe and the Middle East and reduce yield losses caused by them. However, the most promising, spinosad and B. thuringiensis, showed substantial differences in terms of their side-effects. Spinosad caused detrimental effects on predatory mites and was associated with a decline in the parasitization rate of leafhoppers. It was also associated with an increase in leafhopper population densities as a possible consequence of detrimental effects on beneficials. In contrast, B. thuringiensis proved to be selective, confirming data coming from the literature, and did not promote outbreaks of secondary pests. Differences between the two insecticides probably depend on their mode of action towards the target and non-target arthropods. Bacillus thuringiensis acts through ingestion, while spinosad through contact and ingestion. For a long time, the use of $B$. thuringiensis has been relegated to organic viticulture, but our results showed its potential in farms managed with Integrated Pest Management (IPM).

Author Contributions: Conceptualization, C.D.; methodology, C.D., S.S. and B.B.; formal analysis, A.P. and C.D.; investigation, C.D., P.T., D.F., S.S., B.B. and M.L.; resources, C.D.; data curation, C.D., P.T., D.F., S.S., B.B. and M.L.; writing-original draft preparation, C.D. and A.P.; writing-review and editing, S.S. and B.B.; supervision, C.D.; funding acquisition, C.D. All authors have read and agreed to the published version of the manuscript.

Funding: This research was funded by the Seventh framework programme of the European Community grant number 265865 and by the Regione del Veneto PSR Veneto 2014-2020, DGR N. 736/2018, Misura 16 "Cooperazione" grant number 4113850.

Institutional Review Board Statement: Not applicable.

Informed Consent Statement: Not applicable.

Data Availability Statement: The data presented in this study are available from the corresponding author, upon reasonable request.

Conflicts of Interest: The authors declare no conflict of interest.

\section{References}

1. Harari, A.R.; Zahavi, T.; Steinitz, H. Female detection of the synthetic sex pheromone contributes to the efficacy of mating disruption of the European grapevine moth. Lobesia Botrana Pest Manag. Sci. 2015, 71, 316-322. [CrossRef] [PubMed]

2. Reineke, A.; Thiéry, D. Grapevine insect pests and their natural enemies in the age of global warming. J. Pest Sci. 2016, 89, 313-328. [CrossRef]

3. Gilligan, T.M.; Epstein, M.E.; Passoa, S.C.; Powell, J.A.; Sage, O.C.; Brown, J.W. Discovery of Lobesia botrana (Denis \& Schiffermuller) in California; an invasive species new to North America (Lepidoptera: Tortricidae). Proc. Entomol. Soc. Wash. 2011, 113, 14-30.

4. Gutierrez, A.P.; Ponti, L.; Cooper, M.L.; Duso, C. Prospective analysis of the invasive potential of the European grapevine moth Lobesia botrana (Den. \& Schiff.) in California. Agric. For. Entomol. 2012, 14, 225-238.

5. Pavan, F.; Stefanelli, G.; Villani, A.; Cargnus, E. Influence of grapevine cultivar on the second generations of Lobesia botrana and Eupoecilia ambiguella. Insects 2018, 9, 8. [CrossRef]

6. Svobodova, E.; Trnka, M.; Dubrovsky, M.; Semeradova, D.; Eitzinger, J.; Stepanek, P.; Zalud, Z. Determination of areas with the most significant shift in persistence of pests in Europe under climate change. Pest Manag. Sci. 2014, 70, 708-715. [CrossRef]

7. Cozzi, G.; Somma, S.; Haidukowski, M.; Logrieco, A.F. Ochratoxin A Management in Vineyards by Lobesia botrana Biocontrol. Toxins 2013, 5, 49-59. [CrossRef] [PubMed]

8. Pavan, F.; Bigot, G.; Cargnus, E.; Zandigiacomo, P. Influence of the carpophagous generations of the European grapevine moth Lobesia botrana on grape bunch rots. Phytoparasitica 2014, 42, 61-69. [CrossRef]

9. Pavan, F.; Cargnus, E.; Bigot, G.; Zandigiacomo, P. Residual activity of insecticides applied against Lobesia botrana and its influence on resistance management strategies. Bull. Insectology 2014, 67, 273-280.

10. Chuche, J.; Thiéry, D. Biology and ecology of the Flavescence dorée vector Scaphoideus titanus: A review. Agron. Sustain. Dev. 2014, 34, 381-403. [CrossRef] 
11. Duso, C.; Pozzebon, A.; Kreiter, S.; Tixier, M.S.; Candolfi, M. Chapter 9. Management of Phytophagous Mites in European Vineyards. In Arthropod Management in Vineyards: Pests, Approaches, and Future Directions; Bostanian, N.J., Vincent, C., Isaacs, R., Eds.; Springer Science and Business Media B.V.: Dordrecht, The Netherlands, 2012; pp. 191-217. [CrossRef]

12. ISTAT. Utilizzo Dei Prodotti Fitosanitari Nella Coltivazione Della Vite. Annata Agraria 2009-2010. 2011. Available online: https:/ / www.istat.it/it/archivio/ fitosanitari (accessed on 17 November 2021).

13. Cini, A.; Ioriatti, C.; Anfora, G. A review of the invasion of Drosophila suzukii in Europe and a draft research agenda for integrated pest management. Bull. Insectology 2012, 65, 149-160.

14. Duso, C.; Zanettin, G.; Gherardo, P.; Pasqualotto, G.; Raniero, D.; Rossetto, F.; Tirello, P.; Pozzebon, A. Colonization Patterns, Phenology and Seasonal Abundance of the Nearctic Leafhopper Erasmoneura vulnerata (Fitch), a New Pest in European Vineyards. Insects 2020, 11, 731. [CrossRef] [PubMed]

15. Ioriatti, C.; Anfora, G.; Tasin, M.; De Cristofaro, A.; Witzgall, P.; Lucchi, A. Chemical ecology and management of Lobesia botrana (Lepidoptera: Tortricidae). J. Econ. Entomol. 2011, 104, 1125-1137. [CrossRef] [PubMed]

16. Cardé, R.T.; Minks, A. Control of moth pests by mating disruption: Successes and constraints. Annu. Rev. Entomol. 1995, 40, 559-585. [CrossRef]

17. Kast, W.K. Twelve years of practical experience using mating disruption against Eupoecilia ambiguella and Lobesia botrana in vineyards of the Wuerttemberg region, Germany. IOBC/WPRS Bull. 2001, 24, 71-73.

18. Shahini, S.; Kullaj, E.; Cakalli, A.; Cakalli, M.; Lazarevska, S.; Pfeiffer, D.G.; Gumeni, F. Population dynamics and biological control of European grapevine moth (Lobesia botrana: Lepidoptera: Tortricidae) in Albania using different strains of Bacillus thuringiensis. Int. J. Pest Man. 2010, 56, 281-286. [CrossRef]

19. Irigaray, F.J.; Moreno-Grijalba, F.; Marco, V.; Perez-Moreno, I. Acute and reproductive effects of Align ${ }^{\circledR}$, an insecticide containing azadirachtin, on the grape berry moth, Lobesia botrana. J. Insect Sci. 2010, 10, 33. [CrossRef]

20. Sterk, G.; Hassan, S.; Baillod, M.; Bakker, F.; Bigler, F.; Blumel, S.; Bogenschutz, H.; Boller, E.; Bromand, B.; Brun, J.; et al. Results of the seventh joint testing programme carried out by the IOBC/WPRS—Working Group Pesticides and Beneficial Organisms. BioControl 1999, 44, 99-117. [CrossRef]

21. Candolfi, M.P.; Bakker, F.; Canez, V.; Miles, M.; Neumann, C.; Pilling, E.; Primiani, M.; Romijn, K.; Schmuck, R.; StorckWeyhermüller, S.; et al. Sensitivity of non-target arthropods to plant protection products: Could Typhlodromus pyri and Aphidius spp. be used as indicator species. Chemosphere 1999, 39, 1357-1370. [CrossRef]

22. Tirello, P.; Pozzebon, A.; Duso, C. The effect of insecticides on the non-target predatory mite Kampimodromus aberrans: Laboratory studies. Chemosphere 2013, 93, 1139-1144. [CrossRef]

23. Vassiliou, V.A. Effectiveness of insecticides in controlling the first and second generations of the Lobesia botrana (Lepidoptera: Tortricidae) in table grapes. J. Econ. Entomol. 2011, 104, 580-585. [CrossRef]

24. Pavlova, A.K.; Dahlmann, M.; Hauck, M.; Reineke, A. Laboratory Bioassays with Three Different Substrates to Test the Efficacy of Insecticides against Various Stages of Drosophila suzukii (Diptera: Drosophilidae). J. Insect Sci. 2017, 17, 8. [CrossRef]

25. Tacoli, F.; Mori, N.; Pozzebon, A.; Cargnus, E.; Da Vià, S.; Zandigiacomo, P.; Duso, C.; Pavan, F. Control of Scaphoideus titanus with natural products in organic vineyards. Insects 2017, 8, 129. [CrossRef] [PubMed]

26. Duso, C.; Ahmad, S.; Tirello, P.; Pozzebon, A.; Klaric, V.; Baldessari, M.; Malagnini, V.; Angeli, G. The impact of insecticides applied in apple orchards on the predatory mite Kampimodromus aberrans (Acari Phytoseiidae). Exp. Appl. Acarol. 2014, 62, 391-414. [PubMed]

27. Ahmad, S.; Pozzebon, A.; Duso, C. Augmentative releases of the predatory mite Kampimodromus aberrans in organic and conventional apple orchards. Crop Prot. 2013, 52, 47-56. [CrossRef]

28. Biondi, A.; Mommaerts, V.; Smagghe, G.; Vinuela, E.; Zappalà, L.; Desneux, N. The non-target impact of spinosyns on beneficial arthropods. Pest Manag. Sci. 2012, 68, 1523-1536. [CrossRef] [PubMed]

29. Ogburn, E.C.; Walgenbach, J.F. Effects of Insecticides Used in Organic Agriculture on Anastatus reduvii (Hymenoptera: Eupelmidae) and Telenomus podisi (Hymenoptera: Scelionidae), Egg Parasitoids of Pestivorous Stink Bugs. J. Econ. Entomol. 2019, 112, 109-114. [CrossRef]

30. Schlesener, D.C.H.; Wollmann, J.; Pazini, J.D.B.; Grützmacher, A.D.; Garcia, F.R.M. Insecticide Toxicity to Drosophila suzukii (Diptera: Drosophilidae) parasitoids: Trichopria anastrephae (Hymenoptera: Diapriidae) and Pachycrepoideus vindemmiae (Hymenoptera: Pteromalidae). J. Econ. Entomol. 2019, 112, 1197-1206. [CrossRef]

31. Ifoulis, A.A.; Savopoulou-Soultani, M. Biological Control of Lobesia botrana (Lepidoptera: Tortricidae) Larvae by Using Different Formulations of Bacillus thuringiensis in 11 Vine Cultivars Under Field Conditions. J. Econ. Entomol. 2004, 97, 340-343. [CrossRef]

32. Vega, F.E.; Goettel, M.S.; Blackwell, M.; Chandler, D.; Jackson, M.A.; Keller, S.; Koike, M.; Maniania, N.K.; Monzon, A.; Ownley, B.H.; et al. Fungal entomopathogens: New insights on their ecology. Fungal Ecol. 2009, 4, 149-159. [CrossRef] 